\title{
Rho-Associated Kinase II (ROCKII) Limits Axonal Growth after Trauma within the Adult Mouse Spinal Cord
}

\author{
Philip Duffy, ${ }^{1}$ Andre Schmandke, ${ }^{1 \star}$ Antonio Schmandke, ${ }^{1 \star}$ Jonathan Sigworth, ${ }^{1}$ Shuh Narumiya, ${ }^{2}$ \\ William B. J. Cafferty, ${ }^{1}$ and Stephen M. Strittmatter ${ }^{1}$ \\ ${ }^{1}$ Program in Cellular Neuroscience, Neurodegeneration and Repair, Yale University School of Medicine, New Haven, Connecticut 06510, and ${ }^{2}$ Department \\ of Pharmacology, Kyoto University Faculty of Medicine, Yoshida, Sakyo-ku, Kyoto 606-8501, Japan
}

Rho GTPases are thought to mediate the action of several axonal growth inhibitors in the adult brain and spinal cord. RhoA has been targeted pharmacologically in both humans and animals to promote neurite outgrowth and functional recovery following CNS trauma. However, rat spinal cord injury studies suggest a complicated and partial benefit of inhibiting Rho or its downstream effector, Rhoassociated kinase (ROCKII). This limited benefit may reflect inhibition of other kinases, poor access, or a minimal role of ROCKII in vivo. Therefore, we studied ROCKII mutant mice to probe this pathway genetically. $R O C K I I^{-1-}$ dorsal root ganglion neurons are less sensitive to inhibition by Nogo protein or by chondroitin sulfate proteoglycan in vitro. We examined adult $R O C K I I^{-1-}$ mice in two injury paradigms, cervical multilevel dorsal rhizotomy and midthoracic dorsal spinal cord hemisection. After dorsal root crush injury, the $\mathrm{ROCKII}^{-1-}$ mice recovered use of the affected forepaw more quickly than did controls. Moreover, multiple classes of sensory axons regenerated across the dorsal root entry zone into the spinal cord of mice lacking ROCKII. After the spinal cord injury, ROCKII ${ }^{-1-}$ mice showed enhanced local growth of raphespinal axons in the caudal spinal cord and corticospinal axons into the lesion site. Improved functional recovery was not observed by Basso Mouse Scale score following dorsal hemisection, likely due to developmental defects in the nervous system. Together, these findings demonstrate that the ROCKII gene product limits axonal growth after CNS trauma.

\section{Introduction}

Axonal regeneration after adult mammalian CNS trauma is impeded by extracellular molecules derived from both astrocytes and oligodendrocytes (Liu et al., 2006; Cafferty et al., 2008). The glial scar is rich in chondroitin sulfate proteoglycans (CSPGs) (McKeon et al., 1991; Jones et al., 2003), ephrins (Bundesen et al., 2003; Goldshmit et al., 2004), and Sema3s (Pasterkamp et al., 2001), all of which are inhibitors of axonal outgrowth. CNS myelin contains an additional group inhibitory molecules including Nogo (Chen et al., 2000; GrandPré et al., 2000; Prinjha et al., 2000), myelin-associated glycoprotein (MAG) (McKerracher et al., 1994; Mukhopadhyay et al., 1994), oligodendrocyte myelin glycoprotein (OMgp) (Wang et al., 2002), ephrinB3 (Benson et al., 2005), netrin (Löw et al., 2008), and RGM (Hata et al., 2006).

A majority of these adult CNS inhibitors activate a signal transduction through the monomeric GTPase, RhoA (Jin and Strittmatter, 1997; Lehmann et al., 1999; Wahl et al., 2000; Shamah et al., 2001; Niederöst et al., 2002; Fournier et al., 2003; Sivasankaran et al., 2004; Conrad et al., 2007). Downstream of RhoA, Rho-associated kinase II (ROCKII) appears to be key in

Received Sept. 18, 2009; revised 0ct. 15, 2009; accepted 0ct. 26, 2009.

This work was supported by grants to S.M.S. from the National Institutes of Health, the Wings for Life Foundation, and the Falk Medical Research Trust.

${ }^{*}$ A.S. and A.S. contributed equally to this work.

Correspondence should be addressed to Stephen M. Strittmatter, Program in Cellular Neuroscience, Neurodegeneration and Repair, Yale University School of Medicine, P.0. Box 9812, New Haven, CT 06536. E-mail: stephen.strittmatter@yale.edu.

DOI:10.1523/JNEUROSCI.4650-09.2009

Copyright $\odot 2009$ Society for Neuroscience $\quad$ 0270-6474/09/2915266-11\$15.00/0 linking to actin filament dynamics and axonal growth inhibition (Yamashita et al., 1999; Neumann et al., 2002; Yamashita et al., 2002; Borisoff et al., 2003; Monnier et al., 2003). There are two ROCK isoforms, ubiquitous ROCKI and brain-specific ROCKII, with the latter being much more prevalent in brain. Both RhoA and ROCKII have been considered targets for promoting axonal regeneration after injury.

RhoA protein can be inactivated by ADP ribosylation via C3 transferase of Clostridium botulinum (Dillon and Feig, 1995). Use of C3 has yielded varying success in spinal cord injury (SCI) (Dergham et al., 2002; Fournier et al., 2003; Sung et al., 2003). Access to the cell interior is key, and the cell permeant Cethrin has entered human trials. For ROCK inhibition, the pyridine derivative Y-27632 inhibits both isoforms of ROCK and has substantially less potency at protein kinase C, mitogen- and stress-activated protein kinase 1, and MAPKactivated protein kinase 2 (Davies et al., 2000; Schmandke et al., 2007). Y-27632 treatment of rodent SCI enhanced recovery (Dergham et al., 2002; Fournier et al., 2003; Ramer et al., 2004; Chan et al., 2005). A high concentration of Y-27632 enhanced recovery but a low dose was detrimental for recovery. The ability of Y-27632 to stimulate astrocytosis, to inhibit various kinases, and to penetrate differentially into tissue may complicate dosing.

To clarify the therapeutic potential of ROCKII, we examined mice lacking ROCKII (Thumkeo et al., 2003). In vitro outgrowth assays reveal that ROCKII $^{-1-}$ neurons are less sensitive to inhibition by Nogo or CSPG. After cervical dorsal rhizotomy, there is greater axon regeneration and behavioral recovery in $\mathrm{ROCKII}^{-1-}$ 


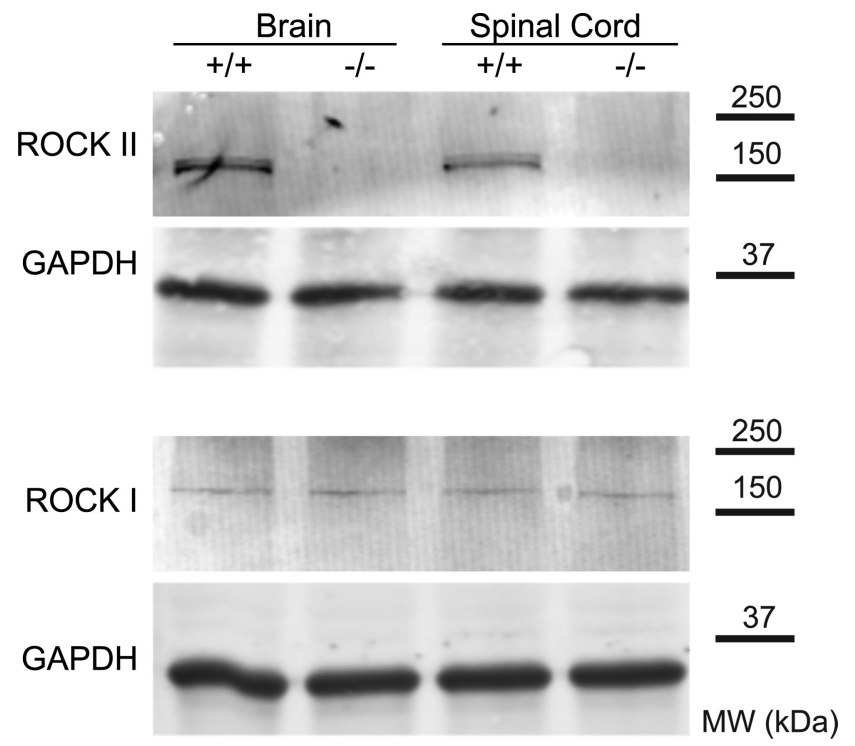

Figure 1. Levels of ROCK protein in $\mathrm{ROCKI}^{-1-}$ mice. Brain and spinal cord tissue from $R O C K I^{-1-}$ and wild-type mice was examined by immunoblot for ROCKII and ROCKI protein. A representative blot for each antigen is shown from one pair of three animals with similar results. Anti-GAPDH immunoblots for the same samples demonstrate equal protein loading. Migration of molecular weight (MW) standards is shown at right.

These studies provide genetic evidence that ROCKII limits axonal growth after adult CNS trauma.

\section{Materials and Methods}

Generation of $\mathrm{ROCKII}^{-1-}$ mice. The generation of $\mathrm{ROCKII}^{-1-}$ mice has been described previously (Thumkeo et al., 2003). It has been reported that $\mathrm{ROCKII}^{-1-}$ embryos are found at the expected Mendelian frequency until $13.5 \mathrm{~d}$ postcoitum, but $\sim 90 \%$ die thereafter in utero due to thrombus formation, placental dysfunction, and intrauterine growth retardation. After additional backcrosses onto a C57BL/6 background, we observed that $<2 \%$ of births from $\mathrm{ROCKII}^{+/-}$crosses were $\mathrm{ROCKII}^{-1-}$. Therefore, the allele was crossed onto a CD-1 (C57BL/6×Dba) background, and then we found that the proportion of $\mathrm{ROCKII}^{-1-}$ mice from heterozygous crosses was close to $25 \%$. In all experiments here, littermate controls were used on the CD-1 background.

ROCK immunoblot. Total homogenates of adult mouse brain and spinal cord were assessed by immunoblot using the following primary antibodies: anti-ROCKII, mouse monoclonal antibody directed against amino acids 906-1012 (BD Transduction Laboratories); anti-ROCKI, mouse monoclonal antibody directed against amino acids 567-718 (BD Transduction Laboratories); and anti-glyceraldehyde 3-phosphate dehydrogenase (anti-GAPDH), rabbit polyclonal antibody (Santa Cruz Biotechnology). Bound antibody was visualized with appropriately labeled secondary antibodies using the Li-COR Odyssey Infrared Imager.
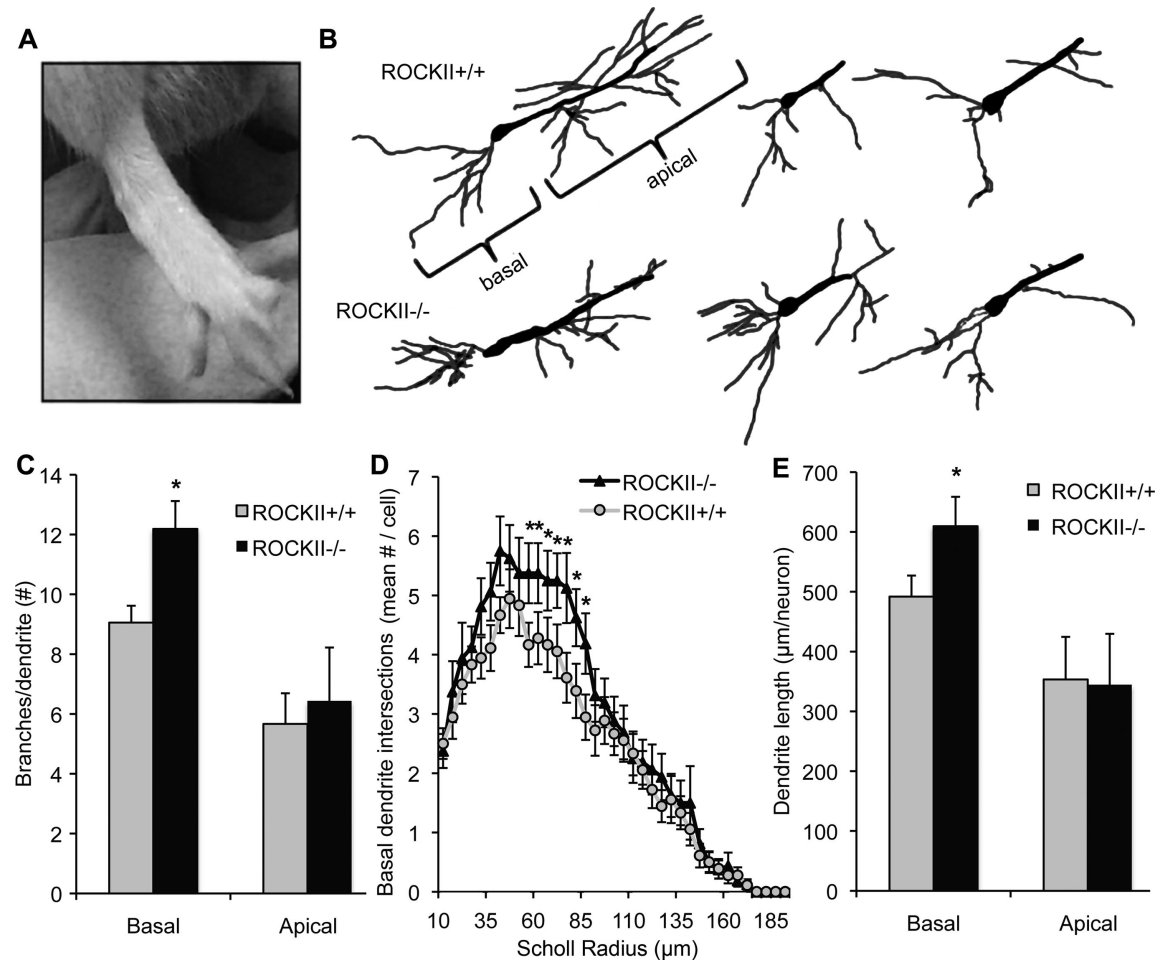

Figure 2. $\quad \mathrm{ROCKII}^{-1-}$ developmental abnormalities. $A, \mathrm{ROCKII}^{-1-}$ pups are frequently born with forepaw and hindpaw digit malformations. $B$, The number of basal and apical dendrite branchpoints in $R O C \mathrm{KII}^{+/+}$and $\mathrm{ROCKII}^{-1-}$ adult $\mathrm{CA} 1$ hippocampal neurons were compared by Golgi staining. $C, R O C K^{-1}{ }^{-1}$ adult mice exhibit a significantly greater number of branchpoints in their basal dendrites compared with $R O C K I^{+/+}$littermates. $\boldsymbol{D}, \boldsymbol{E}, R O C K I^{-1-}$ mice also display an increased number of basal dendrite intersections and dendrite length. All data are mean \pm SEM, one-way ANOVA, $p<0.05$.

mice. After dorsal hemisection of thoracic spinal cord, corticospinal axons of ROCKII-null mice, but not wild-type mice, grow into the lesion site. Raphespinal serotonergic fiber length is increased in the lumbar spinal cord of injured $R_{0 C K I I^{-1-}}$ mice.
Dendrite morphology of hippocampal CA1 pyramidal neurons. Brains from adult ROCKII $^{+/+}$ or $\mathrm{ROCKII}^{-1-}$ mice were fixed by transcardial perfusion, and the brain was dissected and incubated for $5 \mathrm{~d}$ in Golgi solution as previously described (Gibb and Kolb, 1998; Sfakianos et al., 2007). The $25-\mu \mathrm{m}$-thick sections were imaged on a Leica $\mathrm{Z1}$ microscope using the $z$-stack and mosaic functions with a $63 \times$ objective. Protrusions and spines were enumerated and measured using ImageJ software (NIH). The stacks were converted into camera lucida drawings using ImageJ. Apical and basal dendrite lengths, as well as branchpoints and the number of basal spines, were measured. Dendrite complexity was evaluated by Scholl analysis. All analyses were performed by personnel unaware of the genotype of the samples.

Neurite outgrowth assays. Ninety-six-well tissue culture plates (Falcon) were coated with 0-300 ng of Nogo-22 protein or CSPG (Sigma) in PBS and incubated for 2-4 h at room temperature. Without drying, wells were washed and coated with $3 \mu \mathrm{g} / \mathrm{ml}$ laminin (Calbiochem) for $1 \mathrm{~h}$. Adult (4- to 6-month-old) ROCKII $^{-\prime-}(n=4)$ and ROCKII ${ }^{+/+}(n=4)$ dorsal root ganglia (DRGs) were dissociated and plated for $12 \mathrm{~h}$ before fixing with $4 \%$ paraformaldehyde for $15 \mathrm{~min}$. Y-27632 compound (Sigma) was added to selected wells at a concentration of $15 \mu \mathrm{M}$. Neurons were stained by immunofluorescence with anti- $\beta$ III-tubulin (Promega) and appropriate secondary antibody, and cell nuclei with visualized with 4',6diamidino-2-phenylindole (DAPI) (Invitrogen). Neurite outgrowth was quantified by the ImagExpress imaging system and software (MDS Analytical Technologies).

The Nogo-22 protein is the carboxyl 243 amino acid residues of human Nogo-A, containing both of the hydrophobic segments and all three of the regions which interact with NgR1 (Fournier et al., 2001; Hu et al., 2005; Laurén et al., 2007). A cDNA fragment encoding this region was 
subcloned into pGEX-4T-1 to produce a GSTNogo-22 fusion protein in Escherichia coli. After induction of bacterial cultures with IPTG, cells were lysed, and particulate fractions were collected. Membrane-associated protein was extracted with $2 \%$ Triton X-100 and solubilized protein bound to a glutathione-Sepharose resin. The detergent was exchanged with 3 mu lauryldimethylamine oxide, and the fusion protein was cleaved with thrombin. The Nogo-22 protein fragment released from the resin was collected and thrombin was removed by benzamidine-agarose adsorption. The final preparation of Nogo-22 protein prepared under nondenaturing conditions was of $>95 \%$ purity and the yield was $1.6 \mathrm{mg}$ of protein per liter of bacterial culture.

Dorsal rhizotomy and median nerve tracing. Adult (4- to 6-month-old) female ROCKII ${ }^{-1}$ $(n=9), \mathrm{ROCKII}^{+/-}(n=9)$, or ROCKII ${ }^{+/+}$ $(n=9)$ littermates were deeply anesthetized with intraperitoneal ketamine $(100 \mathrm{mg} / \mathrm{kg})$ and xylazine $(15 \mathrm{mg} / \mathrm{kg})$. A hemilaminectomy was performed to expose the lateral portion of spinal cord corresponding to the $\mathrm{C} 4-\mathrm{T} 1 \mathrm{spinal}$ levels. The dura matter overlying dorsal roots C5-C8 was pierced just caudal to each individual root, fine (Dumont \#5) forceps were introduced subdurally between the dorsal root entry zone (DREZ) and DRG, and the left dorsal roots were crushed by squeezing the forceps closed for $5 \mathrm{~s}$. Translucence of injured root demonstrated complete interruption at the time of injury, and histological studies in control groups confirmed complete injury at follow-up. Sham animals $(n=6)$ received hemilaminectomy without root crush. Muscle and skin were sutured with 4.0 vicryl. Three days before perfusion, animals received a $1 \mu \mathrm{l}$ injection of a $1 \%$ solution of cholera toxin $\beta$-subunit (CTB) (List Biological Laboratories) in their left median nerve. All animals were transcardially perfused with $4 \%$ paraformaldehyde. Tissue was postfixed overnight and embedded in $10 \%$ gelatin for immunohistochemical processing.

Dorsal hemisection and corticospinal tract tracing procedure. All surgical procedures and postoperative care were performed in accordance with guidelines of the Yale University Animal Care and Use Committee. Adult (4- to 6-month-old) female ROCKII ${ }^{-1-}(n=10)$, ROCKII $^{+/-}(n=8)$, and ROCKII $^{+/+}(n=7)$ littermate mice were deeply anesthetized with intraperitoneal ketamine $(100 \mathrm{mg} / \mathrm{kg})$ and xylazine $(15 \mathrm{mg} / \mathrm{kg})$. A laminectomy was performed to expose the dorsal portion of spinal cord corresponding to T6 and T7 levels. The dura matter was pierced and the spinal cord was exposed, and a piece of Gelfoam soaked in 1\% lignocaine was placed on the exposed cord for 1 min before lesion. A dorsal overhemisection lesion was performed at $\mathrm{T} 6$ with a 30 gauge needle and a pair of microscissors to a depth of $1.0 \mathrm{~mm}$ to completely sever the dorsal and dorsolateral corticospinal tract (CST). The overlying muscle was sutured with 4.0 vicryl. Sham animals received laminectomy without lesion. One week later, mice received unilateral cortical injections with biotin dextran amine (BDA; 10,000 molecular weight; Invitrogen) to anterogradely label the CST. Burr holes were made over the sensorimotor cortex, and six microinjections were made to a depth of $1.0 \mathrm{~mm}$ (co-ordinates, $0.5-$ $1.5 \mathrm{~mm}$ posterior to bregma and $0.5-1.5 \mathrm{~mm}$ lateral to bregma) to deliver a total volume of $1.2 \mu \mathrm{l}$ of BDA (10,000 molecular weight; Invitrogen). Four weeks after dorsal hemisection, mice were perfused with $4 \%$ paraformaldehyde, postfixed overnight at $4^{\circ} \mathrm{C}$, and embedded in $10 \%$ gelatin for immunohistochemical processing.

Behavioral analysis. The Basso Mouse Scale (BMS) was used to assess mice that underwent dorsal hemisection or sham lesion (Basso et al.,
2006). Mice were assessed weekly for 4 weeks. In addition to a repeatedmeasures ANOVA, mouse BMS scores were compared using a post hoc Fishers protected least significant difference test. ROCKII $^{-/-}$motor function was also assessed in uninjured mice by using the rotarod test. Animals were placed on the revolving beam and rotation began at a speed of $5 \mathrm{rpm}$, increasing at a rate of $0.1 \mathrm{rpm} / \mathrm{s}$. $\mathrm{ROCKII}^{-1-}, \mathrm{ROCKII}^{+/-}$, and $\mathrm{ROCKII}^{+/+}$mice that underwent sham lesion or dorsal rhizotomy were assessed using the spontaneous exploration and thermal withdrawal tests. Baselines for spontaneous exploration were obtained preinjury to assess preferred forelimb use during normal exploratory activity. No pretraining was required in this test, but the recording of baselines doubled as habituation for the animals. Mice were placed in a clear Perspex cylinder (300 $\mathrm{mm}$ in height, $80 \mathrm{~mm}$ in diameter) for the duration of 15 rears. A mirror was placed at an angle behind the cylinder so that the forepaws were visible at all times. The testing was recorded (Canon digital video camera recorder, Elura 2MC) and scored at a later date. Three baselines on three consecutive days were obtained before lesion. The following behaviors were scored: (1) paw used to push off the table when rearing; (2) paw used for weight support during a rear, scored either as an independent use of the right or left paw or as use of both paws for weight support on the wall of the cylinder during a rear, or to regain balance while moving laterally in a vertical position along the wall of the cylinder; and (3) paw used for weight support when landing following a rear. Animals were tested postinjury on days $1,2,3,5,7,14,21$, and 28 . The thermal withdrawal test is a measure of nociceptive sensory function and can be used to measure functional recovery of nociceptive neurons. The forepaws of each animal were dipped into a $52^{\circ} \mathrm{C}$ water bath, and the time taken for them to withdraw their paws was recorded. Animals were tested three times before surgery and on days $1,2,3,5,7,14,21$, and 28 postin- 

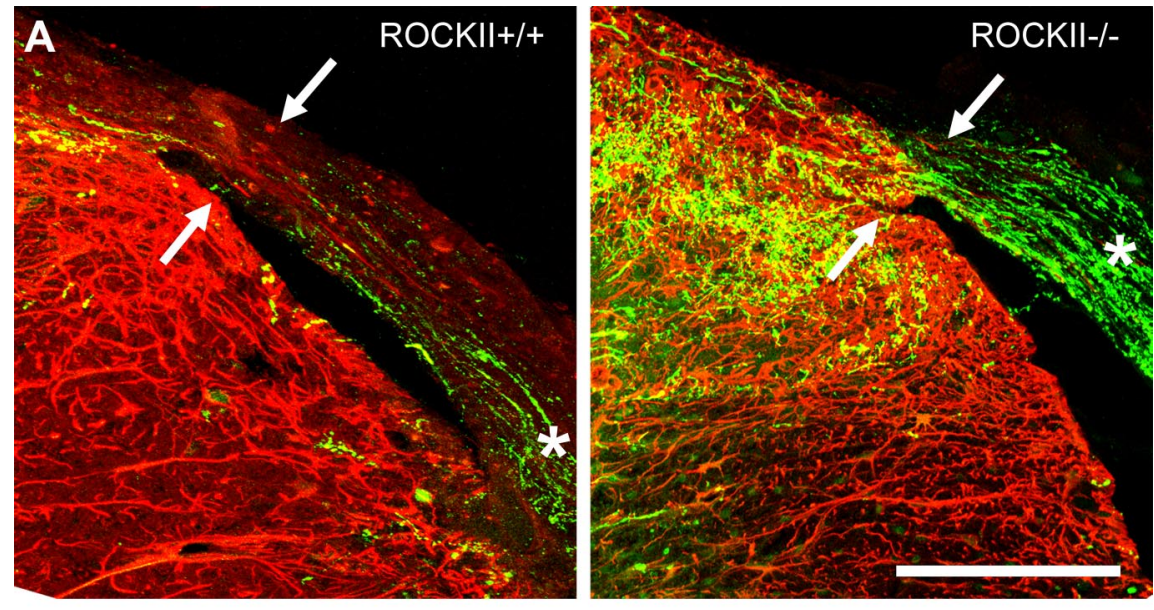

B

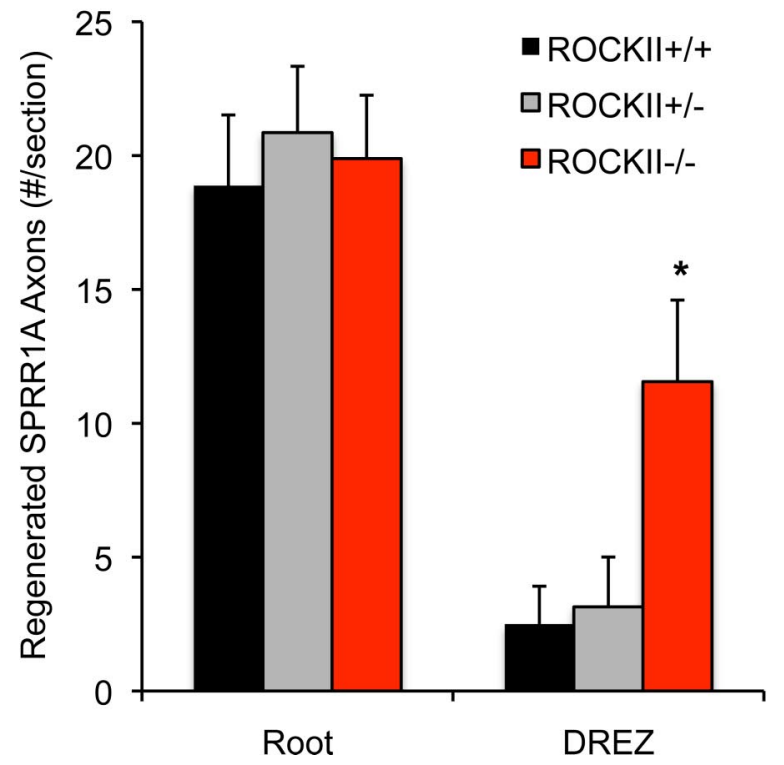

Figure 4. ROCKII gene deletion promotes regeneration of SPRR1A-expressing sensory neurons after rhizotomy. $A$, Photomicrographs illustrate high-power transverse sections of cervical spinal cord from adult ROCKII ${ }^{+/+}$(left) and ROCKII ${ }^{-1-}$ (right) mice which underwent dorsal rhizotomy at cervical spinal cord segments C5-C828 d previously. SPRR1A-immunoreactive axons (green channel) can be seen in the dorsal root of both genotypes (asterisk). However, significantly greater numbers of axons are present entering the DREZ in the $\mathrm{ROCKI}^{-1-}$ group (arrow in right photomicrograph) than in control group (arrow in left photomicrograph, quantified in $\boldsymbol{B}$, asterisk). Reactive CNS tissue is visualized with anti-GFAP immunofluorescence (red channel). Scale bar, 100 $\mu \mathrm{m}$. Mean \pm SEM, one-way ANOVA, $p<0.05$.

jury. Behavioral responses of rhizotomized mice in the spontaneous exploration test were compared using a one-way repeated-measures ANOVA. Post hoc comparisons were made using the Student-NewmanKeuls test. In the thermal withdrawal test, behavioral responses of mice were compared using two-way repeated-measures ANOVA, followed by the Student-Newman-Keuls test.

Immunohistochemistry. Sagittal $25 \mu \mathrm{m}$ sections of spinal cord were cut on a vibratome for immunohistological assessment using antibodies for GFAP (1:10,000 Invitrogen) or 5-HT (1:16,000, Immunostar) with the appropriate AlexaFluor secondary antibodies conjugated to AlexaFluor 488 and 546 (Invitrogen). These counts were averaged for five sections in five animals per group. Analysis of serotonergic fiber length was accomplished with the ImageJ program version 1.62 from NIH as described previously (GrandPré et al., 2002; Kim et al., 2004). Immunoreactive serotonin fibers in the ventral horn of transverse sections rostral or caudal to the lesion were selected by thresholding; then, the length of serotonin fibers per area was measured after using the skeletonize function. Five sections per animal per group were selected for analysis. BDApositive CST axons visualized with tagged avidin and the density is presented as a CST axon index, as previously described (Cafferty et al., 2007).
Briefly, axon numbers were calculated as a ratio of the number of CST axons present at -3 , $-2.5,-2,-1.5,-1,-0.5,0,+0.5$, and +1 $\mathrm{mm}$ (relative to the lesion center) divided by the number of CST axons counted $8 \mathrm{~mm}$ rostral to the lesion site in sagittal sections.

Transverse sections of rhizotomized cervical spinal cord were processed to detect GFAP (antibody at 1:10,000; Invitrogen), chondroitin-4-sulfate (antibody at 1:1000; Millipore Bioscience Research Reagents), small proline-rich protein 1A (SPRR1A) (antibody at 1:1000), calcitonin gene-related peptide (CGRP) (antibody at 1:16,000; Sigma), CTB (1:8000; List Biological Laboratories), and $4^{\prime}, 6^{\prime}$-diamidino-2-phenylindole (DAPI) (dye at 1:10,000; Invitrogen). The average number of regenerating axons (SPRR1A-IR, CGRP-IR, or CTB-IR) was counted in five randomly selected sections containing the DREZ from each animal. The number of axons crossing a line perpendicular to the entering dorsal root is reported as a function of location determined by GFAP immunohistology.

\section{Results \\ ROCKII $^{-/-}$mice develop with impaired motor function}

On an outbred strain background, $\mathrm{ROCKII}^{-1-}$ mice are born at close to Mendelian ratios and most survive to adulthood. Brain and spinal cord tissue from adult $\mathrm{ROCKII}^{-1-}$ mice shows no detectable ROCKII protein expression by immunoblot (Fig. 1). Trace levels of ROCKI protein are present in the adult CNS but are not upregulated in ROCKII $^{-/-}$samples (Fig. 1). Gross examination reveals malformation of digits in the forepaw and hindpaw in essentially all mice (Fig. 2A). To assess one aspect of neuronal morphology in the adult, we used Golgi impregnation to visualize CA1 hippocampal pyramidal neurons (Fig. $2 B)$. The average number of branchpoints is increased for basal dendrites, but not apical dendrites, in mice lacking ROCKII (Fig. 2C). By Scholl analysis, increased branching is detectable within the region $55-85 \mu \mathrm{m}$ from the cell soma (Fig. 2D). Overall, basal dendrite length per neuron is increased in mice lacking ROCKII (Fig. 2 E), but spine density per length of dendrite is unchanged $(1.48 \pm 0.08$ in $\mathrm{ROCKII}^{+/+}$vs $1.45 \pm 0.10$ in $\mathrm{ROCKII}^{-/-}$). It is likely that other morphological aspects of neuronal development are altered in the $\mathrm{ROCKII}^{-/-}$mice because the protein is widely expressed in neurons. As a prelude to SCI, we examined two particular tracts in the adult spinal cord, the raphespinal system was visualized with anti-serotonin antibodies (supplemental Fig. 1, available at www.jneurosci.org as supplemental material) and the corticospinal tract was traced with the anterograde tracer biotin-dextranamine (BDA) (supplemental Fig. 2, available at www.jneurosci. org as supplemental material). These two fiber pathways were indistinguishable between $R O C K I I^{-1-}$ mice and wild-type mice.

To assess the potential functional consequence of altered neuroanatomy in the $\mathrm{ROCKII}^{-1-}$ mice we used a common test of 
generalized motor function, the rotarod. The ability of $\mathrm{ROCKII}^{-/-}$mice to maintain position on a rotating beam is significantly impaired compared with wild-type mice $(161 \pm 8 \mathrm{~s}$ on Rotarod for ROCKII $^{+/+}$mice vs $129 \pm 10 \mathrm{~s}$ for ROCKII $^{-1-}$ mice, $p<0.05$, Student's two-tailed $t$ test). Thus, $R O C K I I^{-/-}$mice are viable but have detectable skeletal defects, neuroanatomical changes and motor dysfunction.

\section{ROCKII gene ablation enhances DRG outgrowth on inhibitory substrates}

To examine the role of ROCKII in mediating myelin and CSPG inhibition of neurite outgrowth, we cultured adult $\mathrm{ROCKII}^{+/+}$and $\mathrm{ROCKII}^{-1-}$ dorsal root ganglion (DRG) neurons on substrates coated with laminin alone, or laminin plus CSPG, or laminin plus Nogo-22 protein. In the absence of inhibitor, basal outgrowth is indistinguishable between $\mathrm{ROCKII}^{-/-}$and $\mathrm{ROCKII}^{+/+}$groups (Fig. $3)$. The presence of Nogo-22 protein significantly reduces wild-type sensory neuron outgrowth, but has no effect on ROCKII $^{-/-}$neurons (Fig. 3A-E). The $\mathrm{Y}-27632$ compound produces a similar rescue from Nogo-22 inhibition (Fig. 3E), consistent with ROCKII mediating Nogo-22 action. A CSPG substrate strongly suppresses outgrowth from wild-type adult DRG neurons (Fig. 3F-J). Neurons lacking ROCKII show three times greater outgrowth than wild-type neurons on CSPG (Fig. 3G,I,J) and Y-27632 shows a trend toward increasing outgrowth on CSPG (Fig. 3J). These data demonstrate that ROCKII is essential for all of Nogo-22 inhibition and a significant fraction of CSPG inhibition of axonal growth from adult DRG neurons.
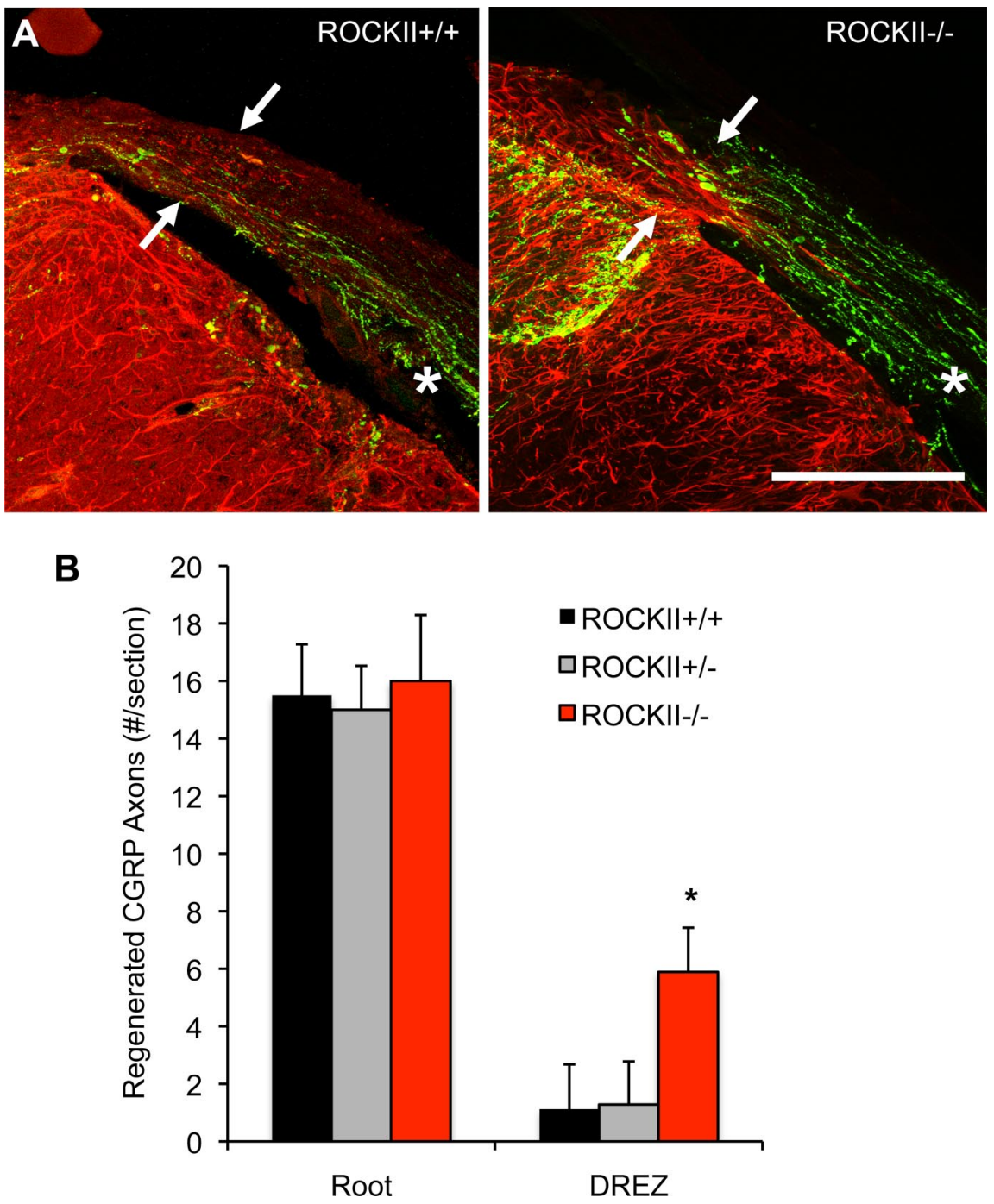

Figure 5. ROCKII gene deletion promotes regeneration of CGRP-expressing sensory neurons after rhizotomy. $\boldsymbol{A}$, Photomicrographs illustrate high-power transverse sections of cervical spinal cord from adult $R O C K I^{+/+}$(left) and $R O C K I I^{-I-}$ (right) mice which underwent dorsal rhizotomy at cervical spinal cord segments C5-C828 d previously. CGRP-immunoreactive axons can be seen in the dorsal root of both genotypes (asterisk, both photomicrographs). However, significantly greater numbers of axons are present entering the DREZ in the ROCKII ${ }^{-1-}$ group (arrow in right photomicrograph) than in control group (arrow in left photomicrograph, quantified in $\boldsymbol{B}$, asterisk). Anti-GFAP immunofluorescence is shown in the red channel. Scale bar, $100 \mu \mathrm{m}$. Mean $\pm \mathrm{SEM}$, one-way ANOVA, $p<0.05$.

\section{Sensory axon regeneration in $\mathrm{ROCKII}^{-/-}$mice following cervical dorsal rhizotomy}

To assess in vivo consequence of the in vitro DRG neurite outgrowth assays, unilateral cervical rhizotomies (segments 5-8 inclusive) were performed on $\mathrm{ROCKII}^{+/+}, \mathrm{ROCKII}^{+/-}$, and $\mathrm{ROCKII}^{-/-}$mice. This lesion axotomizes the central branches of sensory neurons entering the spinal cord at spinal segments C5-8 and results in a deficit of forelimb sensory function ipsilaterally. After rhizotomy in $\mathrm{ROCKII}^{+/+}$and $\mathrm{ROCKII}^{+/-}$ mice, axonal regeneration proceeds through the PNS area of the dorsal root, but stops abruptly upon reaching the DREZ (Fig. 3-5), which delineates the PNS/CNS interface. Anatomical regeneration of various populations of sensory neurons was assessed with several markers. SPRR1A is expressed by regenerating axons (Bonilla et al., 2002; Cafferty et al., 2007) and neurons positive for this marker extend up to, but not through, the DREZ in control wild-type mice. The regeneration of SPRR1A-positive axons is dramatically different in $\mathrm{ROCKII}^{-/-}$mice, with many more axons extending into and through the GFAP-positive area of the dorsal root to enter the CNS (Fig. 4).

We considered whether this regenerative capacity is manifest by different populations of ROCKII $^{-1-}$ sensory neurons. Some DRG neurons are nociceptive in nature, characterized by small-diameter cell bodies with thin or unmyelinated axons whose central branches enter the spinal cord via the DREZ and terminate in the superficial dorsal horn of the spinal cord. One subset of these nociceptors are identified by their expression of CGRP. In $\mathrm{ROCKII}^{+/+}$and $\mathrm{ROCKII}^{+/-}$mice following rhizotomy, regenerating axons approach the damaged DREZ, but very few axons extend into and past the DREZ containing GFAP-positive astrocytes (Fig. 5). In contrast, ROCKII $^{-/-}$CGRP-positive axons traversing the DREZ and enter the spinal cord in significant numbers (Fig. $5 A, B$ ).

Large-diameter myelinated axons, which are involved in proprio- and mechano-sensation, can be specifically labeled by virtue of their ability to internalize and transport CTB. Regenerating CTB-positive axons were seen approaching the damaged DREZ in $\mathrm{ROCKII}^{+/+}$and $\mathrm{ROCKII}^{+/-}$mice (Fig. 6), but the 

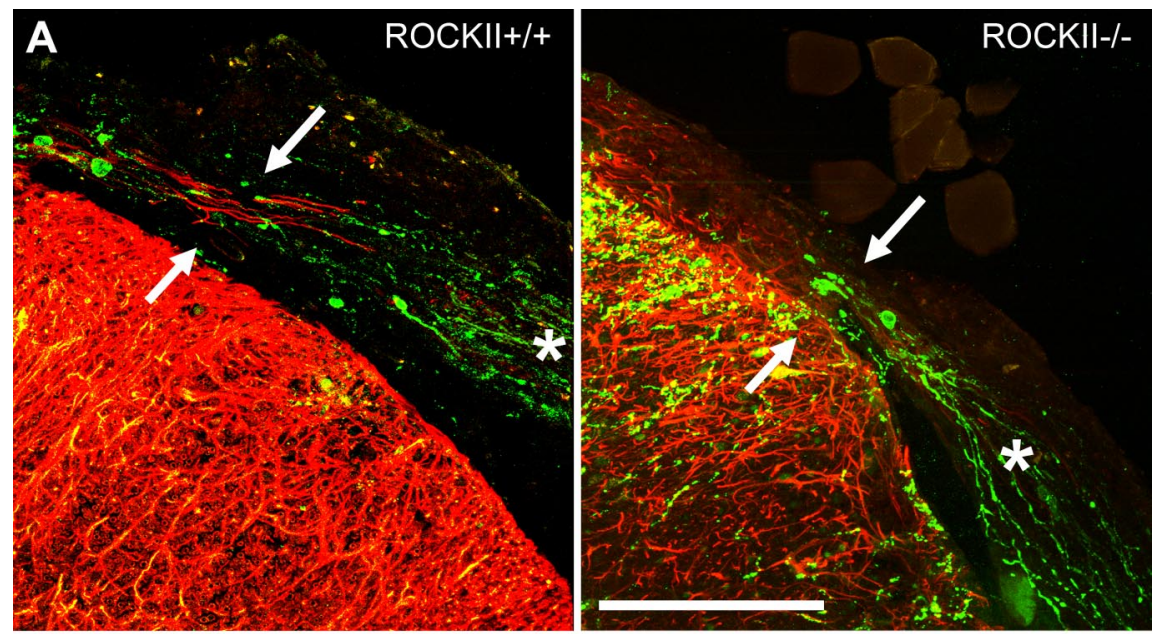

B

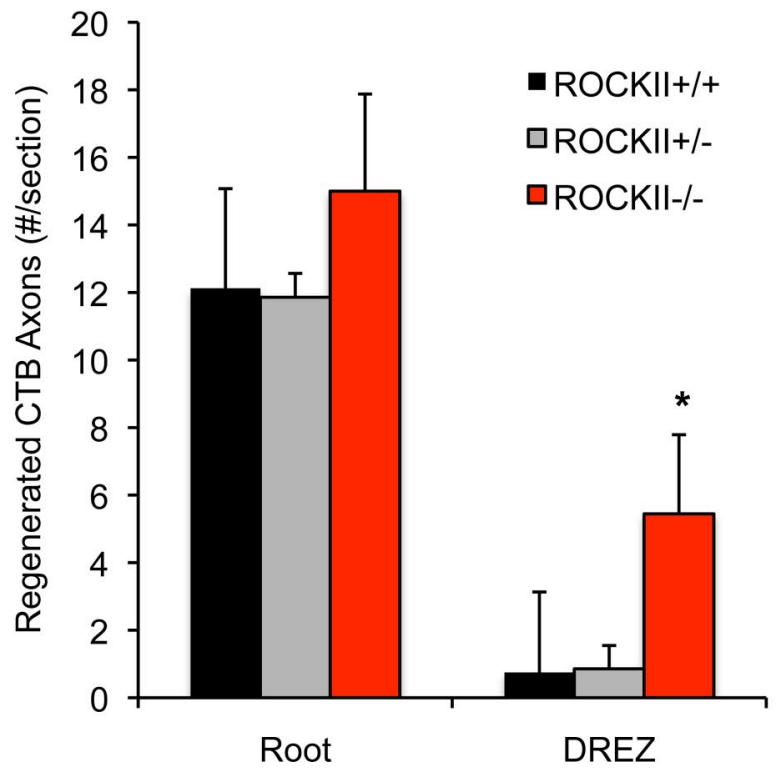

Figure 6. ROCKII gene deletion promotes regeneration of (TB-labeled sensory neurons after rhizotomy. $\boldsymbol{A}$, Photomicrographs illustrate high-power transverse sections of cervical spinal cord from adult $\mathrm{ROCKI}^{+/+}$(left) and $\mathrm{ROCKI}^{-1-}$ (right) mice which underwent dorsal rhizotomy at cervical spinal cord segments C5-C8 $28 \mathrm{~d}$ previously. (TB-labeled axons (green channel) can be seen in the dorsal root of both genotypes (asterisk, both photomicrographs). However, significantly greater numbers of axons are present entering the DREZ in the ROCKII ${ }^{-1-}$ group (arrow in right photomicrograph) than in control group (arrow in left photomicrograph, quantified in $\boldsymbol{B}$, asterisk). Reactive astrocytes are visualized by anti-GFAP immunofluorescence (red channel). Scale bar, $100 \mu \mathrm{m}$. Mean \pm SEM, one-way ANOVA, $p<0.05$.

growth of regenerating axons is arrested at the site of GFAPpositive astrocytes. In contrast, $\mathrm{ROCKII}^{-/-}$mice show significant numbers of CTB-positive axons growing into and past the damaged DREZ (Fig. 6).

\section{Neurological recovery following cervical dorsal root crush injuries}

We sought to determine whether the regeneration of sensory axons through the DREZ is correlated functionally with behavioral recovery using a spontaneous exploration test. When placed in a Perspex cylinder, mice will rear to explore their surroundings. Prelesion, animals use each forelimb individually and in combination to explore (Fig. 7A). Following injury, the use of the affected forelimb for exploration is significantly reduced in each group (Fig. $7 B$ ). However, ROCKII ${ }^{-1-}$ animals show a significant restitution of function by $5 \mathrm{~d}$ compared with $\mathrm{ROCKII}^{+/-}$ and $\mathrm{ROCKII}^{+/+}$groups. By $28 \mathrm{~d}$ postinjury, recovery is substantial in all groups, and there are no statistically differences (Fig.
7B). Anatomical tracing at $2-5 \mathrm{~d}$ postrhizotomy with CTB might strengthen the correlation of anatomy with function but this is not technically feasible due to the time required for transport from the median nerve and potential conditioning effect of manipulating the nerve at the time of rhizotomy.

To assess a selective contribution of ROCKII-dependent nociceptive axon regeneration to recovery, we examined thermal withdrawal in rhizotomized mice. The time taken for $\mathrm{ROCKII}^{+/+}$, $\mathrm{ROCKII}^{+/-}$, and $\mathrm{ROCKII}^{-1-}$ mice to withdraw their forepaws from $52^{\circ} \mathrm{C}$ water was recorded prelesion and on 1, 2, 3, 5, 7, 14, 21, and $28 \mathrm{~d}$ after lesion (Fig. 7C). Each group had similar baseline withdrawal times. At the first time point after injury, withdrawal of the injured forelimb from the $52^{\circ} \mathrm{C}$ water was absent. By the fifth day postinjury however, mice in each group had recovered thermal sensation and withdrawal times in all groups were less than naive mice, reflecting development of equal hyperalgesia in all three groups. The robust recovery in sensation in the control groups cannot be mediated by axon regeneration through the injured DREZ, as evidenced by lack of regeneration of CGRP-expressing axons in both $\mathrm{ROCKII}^{+/+}$and $\mathrm{ROCKII}^{+/-}$ groups (Fig. 5). It may have occurred via development of hypersensitivity and/or spinal rearrangements of spared spinal axons (Abad et al., 1989; Darian-Smith, 2004; Ramer et al., 2004). Thus, this model does allow selective assessment of enhanced CGRP regeneration to functional recovery but demonstrates that the absence of ROCKII does not alter injury-induced hyperalgesia.

\section{Midthoracic dorsal hemisection of the spinal cord}

Given the robust growth of $R O C K I I^{-1-}$ sensory axons in vitro and in vivo, we explored whether motor recovery from spinal cord injury might be greater in mice lacking ROCKII. Dorsal hemisection injuries were created in the midthoracic spinal cord of 2-3-month-old mice. Open field locomotor scores (BMS) reveal no difference in functional recovery between genetic groups at any time point (Fig. 8). The lack of motor recovery detectable with this particular instrument might be due to a specific role for ROCKII in sensory systems or to the observation that $\mathrm{ROCKII}^{-1-}$ have neurodevelopmental deficits with impaired baseline motor function (Fig. 2). Therefore, we examined growth of descending axons in the $\mathrm{ROCKII}^{-/-}$spinal cord after the hemisection injury.

Increased raphespinal axon length in the caudal spinal cord of injured $\mathrm{ROCKII}^{-/-}$mice

Serotonergic neurons of the raphespinal tract contribute significantly to locomotion in rodents and can be examined immuno- 

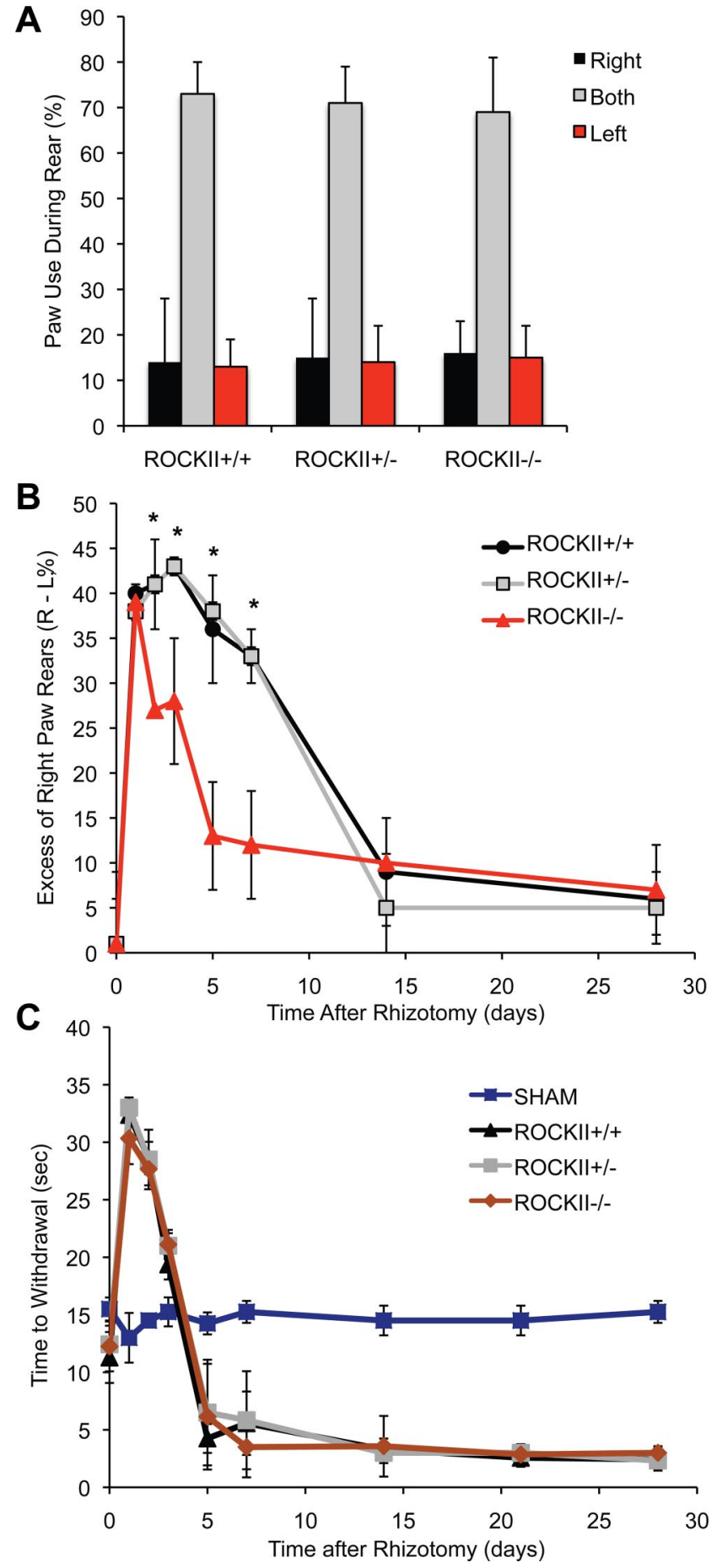

Figure 7. $R O \mathrm{CKII}^{-1-}$ behavioral recovery following cervical rhizotomy. $A$, Prelesion, forelimb use during rearing is not significantly different between $\mathrm{ROCKII}^{+/+}, \mathrm{ROCKI}^{+/-}$, and $R O C K_{I} I^{-I-}$ groups. B, Following injury, $R O C K I^{-I-}$ mice display a reduced dependency on uninjured paw for exploration during a rear by $3 \mathrm{~d}$ postlesion (asterisk). This trend is continued until $15 \mathrm{~d}$ postlesion, by which time groups are not significantly different from each other. $C, R O C \mathrm{KII}^{-1-}$ mice do not display enhanced recovery of thermal sensation following rhizotomy. Withdrawal times after the thermal stimulus were not significantly difference between animal groups at any time point. Injured groups showed decreased withdrawal latencies at early time points postinjury. This trend was not present at $>5 \mathrm{~d}$ postinjury, when animals in each injured group had become hypersensitive to the thermal stimulus. Hypersensitivity continued throughout the remainder of the testing period. Mean \pm SEM, 1 WAY ANOVA, $p<0.05$.

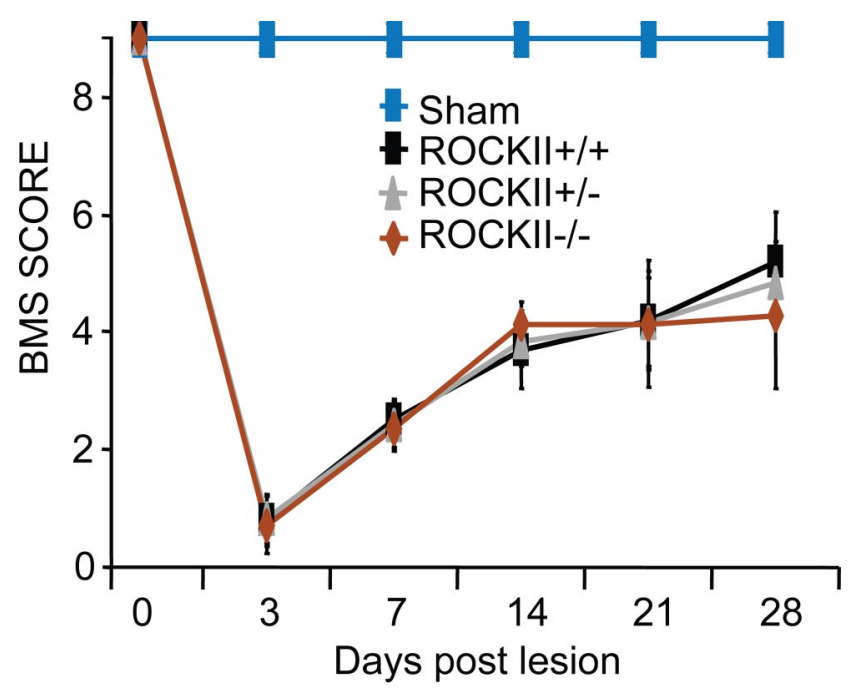

Figure 8. $\quad$ ROCKII ${ }^{-1-}$ mice do not display enhanced recovery in the Basso Mouse Scale open field locomotor test following hemisection. $\mathrm{ROCKII}^{+/+}$(black), $\mathrm{ROCKII}^{+/-}$(brown), $\mathrm{ROCKII}^{-I-}$ (red), and sham (gray, genotypes combined) mice underwent open field locomotor assessment after hemisection lesion. $\mathrm{ROCKII}^{+/+}$(black), $\mathrm{ROCKII}^{+/-}$(brown), and ROCKII ${ }^{-1-}$ (red) groups all exhibited significant deficits in BMS scores following injury compared with sham (gray) animals, which was maintained throughout the testing period (asterisk). No statistical difference was observed between injured groups at any time point. Mean \pm SEM.

histologically with an anti-5-hydroxy-tryptamine (5HT) antibody. Raphespinal anatomy was examined at 6 weeks after injury. Rostral to the lesion, 5HT immunolabeling shows that raphespinal fiber length in the ventral horn gray matter is not significantly different between genotypes (Fig. 9A,B). Raphespinal fiber length is decreased but not eliminated in all groups caudal to the lesion (Fig. $9 A, C$ ). However, ROCKII ${ }^{-1-}$ animals exhibit significantly greater fiber length than do $\mathrm{ROCKII}^{+/-}$and $\mathrm{ROCKII}^{+/+}$ controls. Since these measurements are made in fixed specimens several weeks after SCI they cannot distinguish differences in axonal sparing from axonal sprouting from axonal regeneration. Nonetheless, the net effect is of greater lumbar spinal cord raphepsinal innervation in mice lacking ROCKII.

\section{ROCKII gene deletion allows CST axons into scar tissue}

The CST is crucial for voluntary skilled motor function in humans. The mouse dorsal hemisection lesion model severs the main CST running in the ventral portion of the dorsal columns, as well as the minor, but functionally significant, component running in the lateral funiculus, while sparing extremely rare uncrossed ventral fibers. We examined the CST projection pattern in $\mathrm{ROCKII}^{+/+}, \mathrm{ROCKII}^{+/-}$, and $\mathrm{ROCKII}^{-1-}$ mice by anterograde BDA tracing 6 weeks after bilateral dorsal overhemisection lesions of the midthoracic spinal cord. CST axons are seen approaching the lesion site in $\mathrm{ROCKII}^{+/-}$and ROCKII ${ }^{+/+}$mice, but stop abruptly $\sim 3 \mathrm{~mm}$ rostral to the lesion center (Fig. 10A). ROCKII ${ }^{-1-}$ mice exhibit large numbers of BDA-positive CST axons entering the lesion site (Fig. 10A). Quantification of the number of CST axons present at the lesion site reveals significantly greater numbers of axons for $\mathrm{ROCKII}^{-\prime-}$ mice than ROCKII $^{+/-}$and $\mathrm{ROCKII}^{+/+}$controls (Fig. $10 \mathrm{~B}$ ). The presence of these fibers may reflect either enhanced regeneration or reduced dieback of CST axons. However, their branched profiles and the documentation of sensory axon regeneration (Figs. 4-6) suggest that CST axons regenerate into the scar tissue of ROCKII $^{-1-}$ mice. Despite this evidence for CST growth in in- 

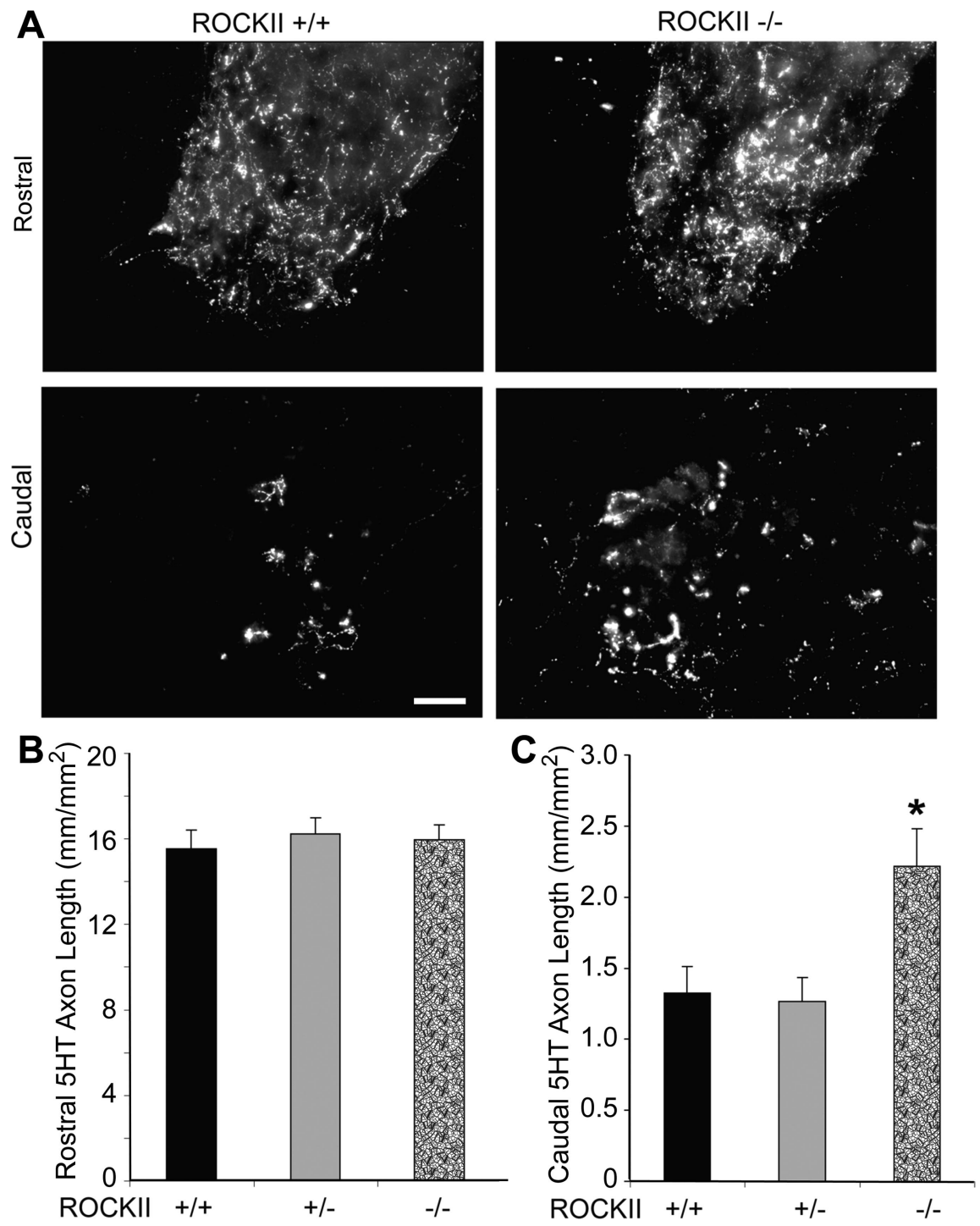

Figure 9. $\mathrm{ROCKII}^{-1-}$ raphespinal fiber length is increased caudal to a hemisection. A, Photomicrographs of 5-HTimmunopositive serotonergic raphespinal tract neurons in transverse sections of ventral horn gray matter rostral (top panel) and caudal (second panel) to a hemisection lesion. $\boldsymbol{B}$, Raphespinal tract fiber lengths are not significantly different between $R O C K I I^{+/+}, R O C K I I^{+/-}$, and $R O C K I I^{-1-}$ animals rostral to a lesion. C, Caudal to a lesion, $R O C K I I^{-1-}$ animals exhibit significantly greater fiber length compared with $\mathrm{ROCKII}^{+/+}$and $R O C \mathrm{KII}^{+/-}$mice (asterisk). Mean $\pm \mathrm{SEM}$, one-way ANOVA, $p<0.05$. Scale bar $100 \mu \mathrm{m}$.

jured ROCKII $^{-1-}$ mice, no BDA-positive CST axons were observed caudal to the lesion.

\section{Discussion}

We provide the first genetic evidence that the Rho signaling pathway limits the axonal growth and neurological recovery after adult mammalian CNS injury. By targeting this pathway, it may be possible to surmount the inhibitory influence of multiple inhibitors by virtue of their convergence on a single signaling molecule. Here, we demonstrate that genetic ablation of the ROCKII expression supports increased in vitro neurite outgrowth potential on both myelin-associated and CSPG inhibitory substrates. In vivo, deletion of ROCKII resulted in sensory neuron regeneration and behavioral recovery following rhizotomy, or CST plus raphespinal tract axon regrowth following spinal cord hemisection.

RhoA and ROCKII have been implicated in numerous axonal guidance events during development, such as participation in eph- rin signaling, RGM signaling, and LPA signaling (Jalink et al., 1994; Jin and Strittmatter, 1997; Kranenburg et al., 1999; Lehmann et al., 1999; Wahl et al., 2000; Shamah et al., 2001). Rho family proteins share extensive cross talk and other family members have been shown to contribute to netrin, slit, and semaphorin action in model systems (Nobes and Hall, 1994; Rohm et al., 2000; Driessens et al., 2001, 2002; Liu and Strittmatter, 2001; Wong et al., 2001; Li et al., 2002; Perrot et al., 2002; Swiercz et al., 2002; Zanata et al., 2002; Jin et al., 2005). In this regard, it is striking that developmental deficits in $\mathrm{ROCKII}^{-1-}$ are relatively mild. The abnormalities of hippocampal dendrite morphology are consistent with findings from studies of mice lacking the p190RhoGAP-interacting kinase Arg (Hernández et al., 2004; Sfakianos et al., 2007). Axonal projections of the uninjured raphespinal and CST systems are indistinguishable from normal in ROCKII $^{-1-}$ mice. Although musculoskeletal abnormalities are present, the ROCKII-null mice have motor performance in the open field and on the rotarod that is close to normal. The paucity of neurodevelopmental abnormalities allowed us to focus on regenerative responses.

The in vitro evidence presented in this paper demonstrating insensitivity of neurite outgrowth from ROCKII-null sensory neurons to Nogo-22 is consistent with results published previously using crude CNS myelin inhibitory substrates and pharmacological inhibitors of RhoA or ROCKI/II (Lehmann et al., 1999; Dergham et al., 2002; Fournier et al., 2003). The results in this paper identify ROCKII as a specific Rho kinase acting to limit neurite outgrowth and extension. The findings provide genetic evidence that Nogo receptor signaling requires ROCKII.

Pharmacological inhibition of RhoA or ROCKI/II has also been shown to stimulate CST axon growth in vitro when cortical neurons were plated on CSPG substrates (Dergham et al., 2002). We found that CSPG inhibition of neuronal outgrowth was reduced but not eliminated in $\mathrm{ROCKII}^{-1-}$ neurons. This implies that CSPG inhibition occurs by both ROCKII-dependent and ROCKII-independent pathways.

The cervical rhizotomy study provides clear evidence that adult axons lacking ROCKII can regenerate across the DREZ barrier that stops wild-type axons. This barrier is formed by both CNS myelin and reactive astrocytes. The growth of large- and small-fiber subtypes of ROCKII-deficient sensory axons through the barrier is consistent with the in vitro growth of ROCKII-null axons in the presence of Nogo or CSPG. Importantly, the increased axonal growth after cervical rhizotomy was associated with increased use of the affected paw. 
After spinal cord injury there is little axonal growth in the adult CNS of wildtype mice. The pattern in $R O C K I I^{-1-}$ mice was dramatically different with many CST axons extending into astroglial scar tissue and nearly double the length of raphespinal axons in the ventral horn of the caudal spinal cord. Thus, we can conclude that endogenous ROCKII contributes to limiting axonal growth after spinal cord trauma. Because we examined raphespinal and CST axons at 6 weeks postinjury, the spinal cord experiment cannot rule out effects on protection of injured fibers from loss or dieback after injury. However, the in vitro outgrowth effects and the axon regeneration after rhizotomy suggest that the changes in CST and raphespinal axons reflect new growth after injury. The behavioral recovery measured by BMS was no greater in the $\mathrm{ROCKII}^{-1-}$ mice after spinal cord injury despite more descending axons in the spinal cord. More demanding tasks and more sensitive measures might uncover slight benefit of ROCKII gene deletion for behavioral recovery from SCI. The limited or nil improvement of spinally injured $\mathrm{ROCKII}^{-l-}$ mice is most likely due to developmental abnormalities in multiple pathways, as shown for hippocampal dendrites and for rotarod function before injury. This complication does not occur with pharmacological Y-27632 treatment after SCI.

Altogether, the findings here provide genetic support for the development of selective ROCKII inhibitors as therapeutics for neurological recovery from spinal cord injury and other adult CNS injury.

\section{References}

Abad F, Feria M, Boada J (1989) Chronic amitriptyline decreases autotomy following dorsal rhizotomy in rats. Neurosci Lett 99: 187-190.

Basso DM, Fisher LC, Anderson AJ, Jakeman LB, McTigue DM, Popovich PG (2006) Basso Mouse Scale for locomotion detects differences in recovery after spinal cord injury in five common mouse strains. J Neurotrauma 23:635-659.

Benson MD, Romero MI, Lush ME, Lu QR, Henkemeyer M, Parada LF (2005) Ephrin-B3 is a myelin-based inhibitor of neurite outgrowth. Proc Natl Acad Sci USA 102:10694-10699.

Bonilla IE, Tanabe K, Strittmatter SM (2002) Small proline-rich repeat protein $1 \mathrm{~A}$ is expressed by axotomized neurons and promotes axonal outgrowth. J Neurosci 22:1303-1315.

Borisoff JF, Chan CC, Hiebert GW, Oschipok L,

Robertson GS, Zamboni R, Steeves JD, Tetzlaff W (2003) Suppression of Rho-kinase activity promotes axonal growth on inhibitory CNS substrates. Mol Cell Neurosci 22:405- 416.

Bundesen LQ, Scheel TA, Bregman BS, Kromer LF (2003) Ephrin-B2 and
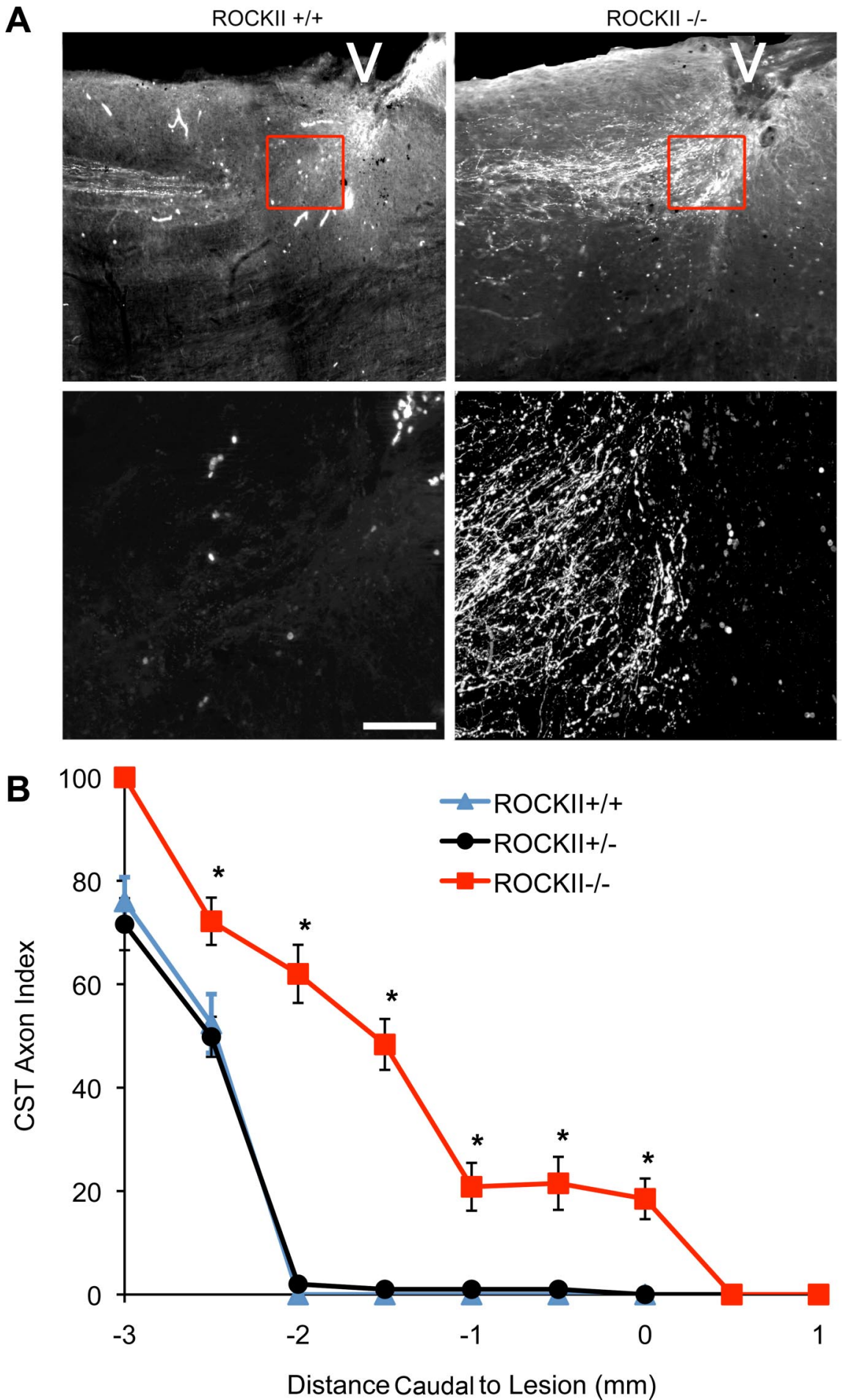

Figure 10. ROCKII gene deletion increases the number of CST axons in the astrocytic scar of an SCl. A, Photomicrographs illustrate sagittal sections of $\mathrm{ROCKI}^{+/+}$(left) and $\mathrm{ROCKII}^{-/-}$(right) mice 6 weeks after hemisection. BDA-immunoreactive CST axons can be seen approaching the lesion site (indicated by the white arrowheads) in both genotypes. High-power magnifications of the lesion area (highlighted boxes in top, shown in bottom) show regenerating CST axons at distances $>3 \mathrm{~mm}$ rostral from the lesion epicenter in $\mathrm{ROCKII}^{+/+}$mice (lower left photomicrograph), whereas $\mathrm{ROCKII}^{-1-} \mathrm{CST}$ axons are present entering the lesion site (lower right photomicrograph). Scale bar, Top, $800 \mu \mathrm{m}$; bottom, $200 \mu \mathrm{m}$. B, Quantification of CST axon growth illustrates that significantly greater numbers of axons are present at various points leading up to the lesion epicenter (mean \pm SEM, 1-way ANOVA, $p<0.05$ ) in $\mathrm{ROCKII}^{-1-}$ animals (red) compared with $\mathrm{ROCKII}^{+/-}$(black) and $\mathrm{ROCKII}^{+/+}$(gray) mice.

EphB2 regulation of astrocyte-meningeal fibroblast interactions in response to spinal cord lesions in adult rats. J Neurosci 23:7789-7800.

Cafferty WB, Yang SH, Duffy PJ, Li S, Strittmatter SM (2007) Functional axonal regeneration through astrocytic scar genetically modified to digest chondroitin sulfate proteoglycans. J Neurosci 27:2176-2185. 
Cafferty WB, McGee AW, Strittmatter SM (2008) Axonal growth therapeutics: regeneration or sprouting or plasticity? Trends Neurosci 31:215-220.

Chan CC, Khodarahmi K, Liu J, Sutherland D, Oschipok LW, Steeves JD, Tetzlaff W (2005) Dose-dependent beneficial and detrimental effects of ROCK inhibitor Y27632 on axonal sprouting and functional recovery after rat spinal cord injury. Exp Neurol 196:352-364.

Chen MS, Huber AB, van der Haar ME, Frank M, Schnell L, Spillmann AA, Christ F, Schwab ME (2000) Nogo-A is a myelin-associated neurite outgrowth inhibitor and an antigen for monoclonal antibody IN-1. Nature 403:434-439.

Conrad S, Genth H, Hofmann F, Just I, Skutella T (2007) Neogenin-RGMa signaling at the growth cone is bone morphogenetic protein-independent and involves RhoA, ROCK, and PKC. J Biol Chem 282:16423-16433.

Darian-Smith C (2004) Primary afferent terminal sprouting after a cervical dorsal rootlet section in the macaque monkey. J Comp Neurol 470: $134-150$.

Davies SP, Reddy H, Caivano M, Cohen P (2000) Specificity and mechanism of action of some commonly used protein kinase inhibitors. Biochem J 351:95-105.

Dergham P, Ellezam B, Essagian C, Avedissian H, Lubell WD, McKerracher L (2002) Rho signaling pathway targeted to promote spinal cord repair. J Neurosci 22:6570-6577.

Dillon ST, Feig LA (1995) Purification and assay of recombinant C3 transferase. Methods Enzymol 256:174-184.

Driessens MH, Hu H, Nobes CD, Self A, Jordens I, Goodman CS, Hall A (2001) Plexin-B semaphorin receptors interact directly with active Rac and regulate the actin cytoskeleton by activating Rho. Curr Biol 11:339-344.

Driessens MH, Olivo C, Nagata K, Inagaki M, Collard JG (2002) B plexins activate Rho through PDZ-RhoGEF. FEBS Lett 529:168-172.

Fournier AE, GrandPre T, Strittmatter SM (2001) Identification of a receptor mediating Nogo-66 inhibition of axonal regeneration. Nature 409:341-346.

Fournier AE, Takizawa BT, Strittmatter SM (2003) Rho kinase inhibition enhances axonal regeneration in the injured CNS. J Neurosci 23: 1416-1423.

Gibb R, Kolb B (1998) A method for vibratome sectioning of Golgi-Cox stained whole rat brain. J Neurosci Methods 79:1-4.

Goldshmit Y, Galea MP, Wise G, Bartlett PF, Turnley AM (2004) Axonal regeneration and lack of astrocytic gliosis in EphA4-deficient mice. J Neurosci 24:10064-10073.

GrandPré T, Nakamura F, Vartanian T, Strittmatter SM (2000) Identification of the Nogo inhibitor of axon regeneration as a Reticulon protein. Nature 403:439-444.

GrandPré T, Li S, Strittmatter SM (2002) Nogo-66 receptor antagonist peptide promotes axonal regeneration. Nature 417:547-551.

Hata K, Fujitani M, Yasuda Y, Doya H, Saito T, Yamagishi S, Mueller BK, Yamashita T (2006) RGMa inhibition promotes axonal growth and recovery after spinal cord injury. J Cell Biol 173:47-58.

Hernández SE, Settleman J, Koleske AJ (2004) Adhesion-dependent regulation of p190RhoGAP in the developing brain by the Abl-related gene tyrosine kinase. Curr Biol 14:691-696.

Hu F, Liu BP, Budel S, Liao J, Chin J, Fournier A, Strittmatter SM (2005) Nogo-A interacts with the Nogo-66 receptor through multiple sites to create an isoform-selective subnanomolar agonist. J Neurosci 25: $5298-5304$.

Jalink K, van Corven EJ, Hengeveld T, Morii N, Narumiya S, Moolenaar WH (1994) Inhibition of lysophosphatidate- and thrombin-induced neurite retraction and neuronal cell rounding by ADP ribosylation of the small GTP-binding protein Rho. J Cell Biol 126:801-810.

Jin M, Guan CB, Jiang YA, Chen G, Zhao CT, Cui K, Song YQ, Wu CP, Poo MM, Yuan XB (2005) $\mathrm{Ca}^{2+}$-dependent regulation of rho GTPases triggers turning of nerve growth cones. J Neurosci 25:2338-2347.

Jin Z, Strittmatter SM (1997) Racl mediates collapsin-1-induced growth cone collapse. J Neurosci 17:6256-6263.

Jones LL, Margolis RU, Tuszynski MH (2003) The chondroitin sulfate proteoglycans neurocan, brevican, phosphacan, and versican are differentially regulated following spinal cord injury. Exp Neurol 182:399-411.

Kim JE, Liu BP, Park JH, Strittmatter SM (2004) Nogo-66 receptor prevents raphespinal and rubrospinal axon regeneration and limits functional recovery from spinal cord injury. Neuron 44:439-451.

Kranenburg O, Poland M, van Horck FP, Drechsel D, Hall A, Moolenaar WH
(1999) Activation of RhoA by lysophosphatidic acid and Galpha12/13 subunits in neuronal cells: induction of neurite retraction. Mol Biol Cell 10:1851-1857.

Laurén J, Hu F, Chin J, Liao J, Airaksinen MS, Strittmatter SM (2007) Characterization of myelin ligand complexes with neuronal Nogo-66 receptor family members. J Biol Chem 282:5715-5725.

Lehmann M, Fournier A, Selles-Navarro I, Dergham P, Sebok A, Leclerc N, Tigyi G, McKerracher L (1999) Inactivation of Rho signaling pathway promotes CNS axon regeneration. J Neurosci 19:7537-7547.

Li X, Saint-Cyr-Proulx E, Aktories K, Lamarche-Vane N (2002) Racl and Cdc42 but not RhoA or Rho kinase activities are required for neurite outgrowth induced by the Netrin-1 receptor DCC (deleted in colorectal cancer) in N1E-115 neuroblastoma cells. J Biol Chem 277:15207-15214.

Liu BP, Strittmatter SM (2001) Semaphorin-mediated axonal guidance via Rho-related G proteins. Curr Opin Cell Biol 13:619-626.

Liu BP, Cafferty WB, Budel SO, Strittmatter SM (2006) Extracellular regulators of axonal growth in the adult central nervous system. Philos Trans R Soc Lond B Biol Sci 361:1593-1610.

Löw K, Culbertson M, Bradke F, Tessier-Lavigne M, Tuszynski MH (2008) Netrin-1 is a novel myelin-associated inhibitor to axon growth. J Neurosci 28:1099-1108.

McKeon RJ, Schreiber RC, Rudge JS, Silver J (1991) Reduction of neurite outgrowth in a model of glial scarring following CNS injury is correlated with the expression of inhibitory molecules on reactive astrocytes. J Neurosci 11:3398-3411.

McKerracher L, David S, Jackson DL, Kottis V, Dunn RJ, Braun PE (1994) Identification of myelin-associated glycoprotein as a major myelinderived inhibitor of neurite growth. Neuron 13:805-811.

Monnier PP, Sierra A, Schwab JM, Henke-Fahle S, Mueller BK (2003) The Rho/ROCK pathway mediates neurite growth-inhibitory activity associated with the chondroitin sulfate proteoglycans of the CNS glial scar. Mol Cell Neurosci 22:319-330.

Mukhopadhyay G, Doherty P, Walsh FS, Crocker PR, Filbin MT (1994) A novel role for myelin-associated glycoprotein as an inhibitor of axonal regeneration. Neuron 13:757-767.

Neumann H, Schweigreiter R, Yamashita T, Rosenkranz K, Wekerle H, Barde YA (2002) Tumor necrosis factor inhibits neurite outgrowth and branching of hippocampal neurons by a rho-dependent mechanism. J Neurosci 22:854-862.

Niederöst B, Oertle T, Fritsche J, McKinney RA, Bandtlow CE (2002) Nogo-A and myelin-associated glycoprotein mediate neurite growth inhibition by antagonistic regulation of RhoA and Racl. J Neurosci 22:10368-10376.

Nobes C, Hall A (1994) Regulation and function of the Rho subfamily of small GTPases. Curr Opin Genet Dev 4:77-81.

Pasterkamp RJ, Anderson PN, Verhaagen J (2001) Peripheral nerve injury fails to induce growth of lesioned ascending dorsal column axons into spinal cord scar tissue expressing the axon repellent Semaphorin3A. Eur J Neurosci 13:457-471.

Perrot V, Vazquez-Prado J, Gutkind JS (2002) Plexin B regulates Rho through the guanine nucleotide exchange factors leukemia-associated Rho GEF (LARG) and PDZ-RhoGEF. J Biol Chem 277:43115-43120.

Prinjha R, Moore SE, Vinson M, Blake S, Morrow R, Christie G, Michalovich D, Simmons DL, Walsh FS (2000) Inhibitor of neurite outgrowth in humans. Nature 403:383-384.

Ramer LM, Borisoff JF, Ramer MS (2004) Rho-kinase inhibition enhances axonal plasticity and attenuates cold hyperalgesia after dorsal rhizotomy. J Neurosci 24:10796-10805.

Rohm B, Rahim B, Kleiber B, Hovatta I, Püschel AW (2000) The semaphorin $3 \mathrm{~A}$ receptor may directly regulate the activity of small GTPases. FEBS Lett 486:68-72.

Schmandke A, Schmandke A, Strittmatter SM (2007) ROCK and Rho: biochemistry and neuronal functions of Rho-associated protein kinases. Neuroscientist 13:454-469.

Sfakianos MK, Eisman A, Gourley SL, Bradley WD, Scheetz AJ, Settleman J, Taylor JR, Greer CA, Williamson A, Koleske AJ (2007) Inhibition of Rho via Arg and p190RhoGAP in the postnatal mouse hippocampus regulates dendritic spine maturation, synapse and dendrite stability, and behavior. J Neurosci 27:10982-10992.

Shamah SM, Lin MZ, Goldberg JL, Estrach S, Sahin M, Hu L, Bazalakova M, 
Neve RL, Corfas G, Debant A, Greenberg ME (2001) EphA receptors regulate growth cone dynamics through the novel guanine nucleotide exchange factor ephexin. Cell 105:233-244.

Sivasankaran R, Pei J, Wang KC, Zhang YP, Shields CB, Xu XM, He Z (2004) PKC mediates inhibitory effects of myelin and chondroitin sulfate proteoglycans on axonal regeneration. Nat Neurosci 7:261-268.

Sung JK, Miao L, Calvert JW, Huang L, Louis Harkey H, Zhang JH (2003) A possible role of RhoA/Rho-kinase in experimental spinal cord injury in rat. Brain Res 959:29-38.

Swiercz JM, Kuner R, Behrens J, Offermanns S (2002) Plexin-B1 directly interacts with PDZ-RhoGEF/LARG to regulate RhoA and growth cone morphology. Neuron 35:51-63.

Thumkeo D, Keel J, Ishizaki T, Hirose M, Nonomura K, Oshima H, Oshima M, Taketo MM, Narumiya S (2003) Targeted disruption of the mouse rho-associated kinase 2 gene results in intrauterine growth retardation and fetal death. Mol Cell Biol 23:5043-5055.

Wahl S, Barth H, Ciossek T, Aktories K, Mueller BK (2000) Ephrin-A5 in- duces collapse of growth cones by activating Rho and Rho kinase. J Cell Biol 149:263-270.

Wang KC, Koprivica V, Kim JA, Sivasankaran R, Guo Y, Neve RL, He Z (2002) Oligodendrocyte-myelin glycoprotein is a Nogo receptor ligand that inhibits neurite outgrowth. Nature 417:941-944.

Wong K, Ren XR, Huang YZ, Xie Y, Liu G, Saito H, Tang H, Wen L, BradyKalnay SM, Mei L, Wu JY, Xiong WC, Rao Y (2001) Signal transduction in neuronal migration: roles of GTPase activating proteins and the small GTPase Cdc42 in the Slit-Robo pathway. Cell 107:209-221.

Yamashita T, Tucker KL, Barde YA (1999) Neurotrophin binding to the p75 receptor modulates Rho activity and axonal outgrowth. Neuron 24:585-593.

Yamashita T, Higuchi H, Tohyama M (2002) The p75 receptor transduces the signal from myelin-associated glycoprotein to Rho. J Cell Biol 157:565-570.

Zanata SM, Hovatta I, Rohm B, Püschel AW (2002) Antagonistic effects of Rnd1 and RhoD GTPases regulate receptor activity in Semaphorin 3Ainduced cytoskeletal collapse. J Neurosci 22:471-477. 